\title{
Analysis of acetylcholine-induced membrane responses in vascular endothelial cells of the guinea-pig mesenteric artery using mefloquine as a gap junction blocker
}

\author{
Yoshimichi YAMAMOTO ${ }^{1,2}$ and Hikaru SUZUKI ${ }^{2}$ \\ ${ }^{1}$ Laboratory of Physiology, Nagoya City University School of Nursing, Japan; \\ ${ }^{2}$ Department of Cell Physiology, Nagoya City University Graduate School of Medical \\ Sciences, Japan
}

Received September 17, 2010; Accepted October 16, 2010

\begin{abstract}
Acetylcholine (ACh)-induced membrane currents were investigated using freshly isolated endothelial layers prepared from the guinea-pig mesenteric artery. Gap junctions were blocked by mefloquine and the whole-cell patch clamp method was applied to individual endothelial cells within each multicellular preparation. While mefloquine effectively blocked the gap junctions, it hyperpolarized the membrane by some $10 \mathrm{mV}$. As this hyperpolarization was absent when the intracellular $\mathrm{Cl}^{-}$concentration was increased, mefloquine may increase the membrane conductance for $\mathrm{Cl}^{-}$. Besides this minor hyperpolarizing effect, mefloquine did not have serious side effects and $\mathrm{ACh}$ could activate a sustained outward current producing a membrane hyperpolarization at concentrations as low as $100 \mathrm{nM}$. At the beginning of ACh application, the reversal potential of the AChinduced current was around the equilibrium potential for $\mathrm{K}^{+}$indicating that this was a $\mathrm{K}^{+}$ current. The reversal potential then gradually became less negative suggesting that other ionic conductances with less negative equilibrium potentials were involved. As the AChinduced outward current was completely blocked by charybdotoxin (CTX, $100 \mathrm{nM}$ ), this current seemed to be due to CTX-sensitive $\mathrm{K}^{+}$channels, possibly $\mathrm{IK}_{\mathrm{Ca}}$ channels. After the $\mathrm{K}^{+}$current had been blocked, ACh gradually activated the membrane current which reversed the polarity at around $-10 \mathrm{mV}$, which was most likely due to $\mathrm{Ca}^{2+}$-activated nonselective cation channels. These ionic conductances may be responsible for the variety in agonist-induced membrane responses observed in different types of vascular preparations.
\end{abstract}

Key words: whole-cell clamp, gap junction blocker, multicellular preparation, nonselective cation channel

\section{Introduction}

In vascular endothelial cells, vasoactive substances such as acetylcholine (ACh) induce membrane hyperpolarization, which then conducts to surrounding smooth muscle cells via 
myoendothelial gap junctions to produce vasodilation (Yamamoto et al., 1999; Yamamoto et al., 2001). ACh and other agonists increase the intracellular concentration of $\mathrm{Ca}^{2+}\left(\left[\mathrm{Ca}^{2+}\right]_{\mathrm{i}}\right)$, which in turn activates both $\mathrm{IK}_{\mathrm{Ca}}\left(\mathrm{K}_{\mathrm{Ca}} 3.1\right)$ and $\mathrm{SK}_{\mathrm{Ca}}\left(\mathrm{K}_{\mathrm{Ca}} 2.3\right)$ channels in many types of vessels. The possible roles of these two kinds of $\mathrm{K}^{+}$channels have been studied (for review, see Grgic et al., 2009). However, agonist-induced membrane responses in vascular endothelial cells are not always a simple hyperpolarization, but vary between different types of preparations. For example, a transient hyperpolarization followed by a depolarization is induced in the intact endothelium of the rat aorta with the smooth muscle layers attached (Marchenko and Sage, 1993). This suggests the involvement of ion channels other than $\mathrm{K}^{+}$channels, although this has not been studied extensively.

To investigate agonist-activated membrane currents, we have been using freshly isolated arterial intima where the endothelial cells maintained their cobblestone alignment, as the electrophysiological data obtained from such preparations are expected to be more physiologically normal than those from either freshly isolated single cells or cultured cells. As the arterial intima consists of thousands of electrically coupled endothelial cells having numerous gap junctions, the number of cells to be controlled needs to be reduced to get proper space-clamp conditions. To achieve such conditions, we have previously used a wide-bore micropipette to destroy a ring of cells, leaving an isolated population of intact cells inside (Yamamoto and Suzuki, 2007). Although the membrane potential of these mechanically-isolated cells could be easily controlled, it was not clear whether the intracellular solution of these cells could be quickly replaced with the pipette solution. In terms of the efficiency of the intracellular dialysis, blocking gap junctions between endothelial cells seems to have some advantage because the patched cell is virtually isolated. The problem is most of the gap junction blockers including $18 \beta$-glycyrrhetinic acid we previously used (Yamamoto et al., 1998) have undesired side effects such as depolarization of the membrane (Coleman et al., 2001).

In pairs of cultured neuroblastoma cells transfected with various connexins (Cx26, Cx32, $\mathrm{Cx} 36, \mathrm{Cx} 43, \mathrm{Cx} 46$ or $\mathrm{Cx} 50$ ), mefloquine, an antimalarial drug, blocks gap junctions composed of either $\mathrm{Cx} 36$ or $\mathrm{Cx} 50$ more potently than those composed of other connexins (Cruikshank et al., 2004). Although higher concentrations are required, mefloquine blocks gap junctions in endothelial cells of guinea-pig mesenteric artery where $\mathrm{Cx} 40$ is mainly expressed (Yamamoto and Suzuki, 2008). In the present experiments, we again employed mefloquine as a gap junction blocker, enabling both the membrane potential and the intracellular ionic condition of the chemically-isolated endothelial cells to be properly controlled. The results indicated that upon application of $\mathrm{ACh}$ to guinea-pig mesenteric artery endothelial cells, $\mathrm{IK}_{\mathrm{Ca}}$ channels were activated quickly followed by a gradual activation of $\mathrm{Ca}^{2+}$-activated non-selective cation channels.

\section{Methods}

\section{Preparations}

Male guinea pigs, weighing 220-285 g, were anesthetized by sevoflurane inhalation and decapitated using an animal guillotine. The animals were treated ethically according to the rules of the Laboratory Animal Care and Use Committee of Nagoya City University Graduate School of Medical Sciences. First or second order branches of mesenteric arteries (diameter 300-400 $\mu \mathrm{m}$ ) 
were dissected out from the mesenteric vasculature of the jejuno-ileal region. Preparations were made as described previously (Yamamoto and Suzuki, 2007). Briefly, a segment of artery was incubated in collagenase solution (nominally $\mathrm{Ca}^{2+}$-free physiological saline containing $0.5 \mathrm{mg} / \mathrm{mL}$ collagenase; Wako Pure Chemical Industries, Ltd., Osaka, Japan) for $30-35 \mathrm{~min}$ at $37^{\circ} \mathrm{C}$. The adventitial and smooth muscle layers were then removed mechanically, leaving the endothelial layer and the internal elastic lamina. The tube lined with the endothelial layer was cut open and pinned down in a small chamber with the luminal surface upward, then superfused with preheated $\left(30^{\circ} \mathrm{C}\right)$ and aerated $\left(100 \% \mathrm{O}_{2}\right)$ bath solution at a constant rate $(1 \mathrm{~mL} / \mathrm{min})$. The dimensions of a typical preparation were approximately $2.5 \mathrm{~mm}$ long and $0.8 \mathrm{~mm}$ wide.

\section{Electrophysiological Techniques}

A patch electrode was applied to individual endothelial cells, and conventional whole-cell clamp experiments performed. Current and voltage signals were acquired using a MultiClamp 700A system (Molecular Devices, Sunnyvale, CA, USA). These signals were digitized with a Digidata 1322A data acquisition system (Molecular Devices). The sampling rate was always five times higher than the cutoff frequency $(-3 \mathrm{~dB})$ of a low-pass Bessel filter. Voltage clamp protocols were controlled with pCLAMP 10 software (Molecular Devices). The liquid junction potentials were measured assuming that the liquid junction potential of an electrode filled with $3 \mathrm{M}-\mathrm{KCl}$ was negligible and compensated for after each experiment manually. While the membrane potential was clamped at a holding potential, a voltage ramp changing from +50 to $-120 \mathrm{mV}$ in $1 \mathrm{~s}$ was applied to monitor the $I-V$ relationship of the current every $10 \mathrm{~s}$. The $I-V$ relationship of the AChinduced current component was obtained by subtracting the $I$ - $V$ relationship of the basal current recorded after washing out of $\mathrm{ACh}$ from that of the original current in the presence of $\mathrm{ACh}$.

\section{Solutions and Chemicals}

The composition of the standard bath solution was (mM) NaCl, $146 ; \mathrm{KCl}, 5.4 ; \mathrm{CaCl}_{2}, 1.8 ; \mathrm{MgCl}_{2}$, 1; HEPES, 10; glucose, 5. The $\mathrm{pH}$ was adjusted to 7.3 using $\mathrm{NaOH}$. The standard pipette solution contained (mM) KCl, 20; K-aspartate, 137; $\mathrm{MgCl}_{2}$, 1; HEPES, 10; glucose, 5; EGTA, 1; ATP-2Na, 2. The high-EGTA pipette solution contained (mM) KCl, 20; K-aspartate, 125; $\mathrm{MgCl}_{2}, 1$; HEPES, 10 ; glucose, 5; EGTA, 10; ATP-2Na, 2. The high- $\mathrm{Cl}^{-}$pipette solution contained (mM) $\mathrm{KCl}, 152 ; \mathrm{MgCl}_{2}$, 1; HEPES, 10; glucose, 5; EGTA, 1; ATP-2Na, 2. The $\mathrm{pH}$ of the pipette solution was adjusted to 6.9 using $\mathrm{KOH}$. The liquid junction potentials measured as the potential of the bath solution with respect to the pipette were +10.4 (for the standard pipette solution), +11.2 (for the high-EGTA pipette solution), and $+3.4 \mathrm{mV}$ (for the high- $\mathrm{Cl}^{-}$pipette solution). The calculated equilibrium potentials of $\mathrm{K}^{+}\left(E_{\mathrm{K}}\right)$ with the standard and high- $\mathrm{Cl}^{-}$pipette solutions were -88 and $-87 \mathrm{mV}$, and $E_{\mathrm{Cl}}$ -51 and $-1 \mathrm{mV}$, respectively. ACh and mefloquine were obtained from Sigma (St. Louis, MO, USA). Mefloquine was dissolved in DMSO to make a stock solution of $10^{-1} \mathrm{M}$. Charybdotoxin (CTX) was obtained from Peptide Institute, Inc. (Osaka, Japan).

\section{Statistics}

Numerical data are represented as the mean $\pm \mathrm{SD}$, with $n$ indicating the number of measurements. For statistical evaluation, a $P$ value $<0.05$ was considered to be significant. 
A

B
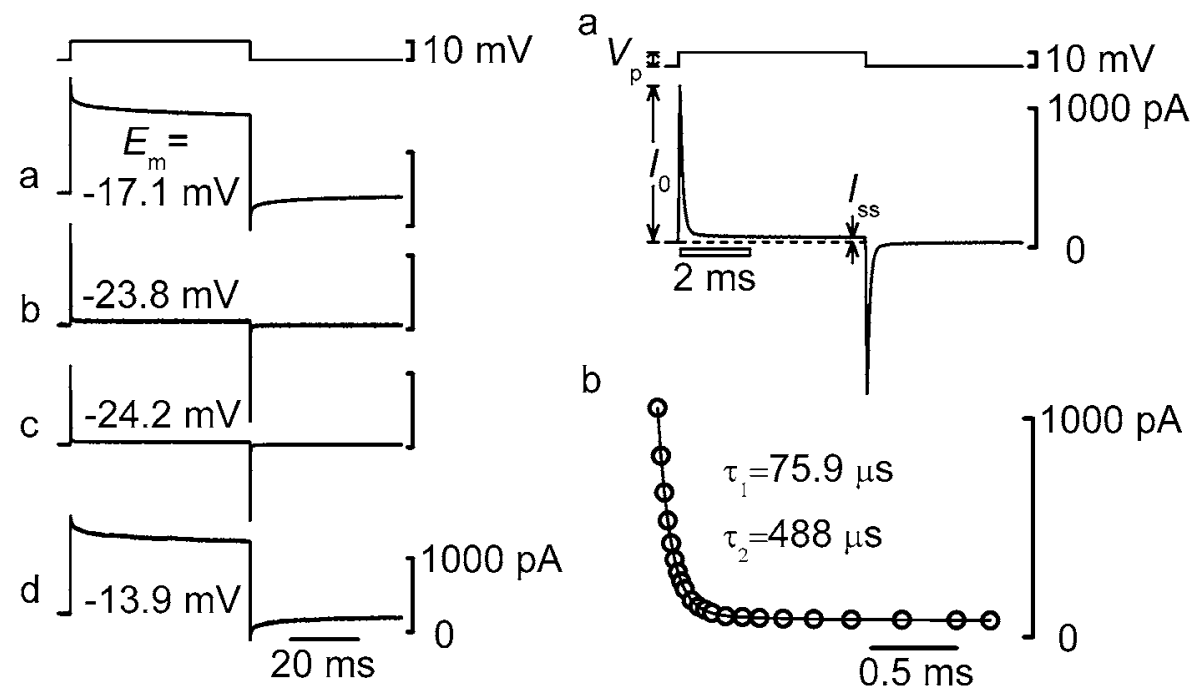

Fig. 1. Effect of mefloquine on gap junctions. A: Effect of mefloquine $(30 \mu \mathrm{M})$ on the membrane currents required to impose a $10 \mathrm{mV}$ voltage clamp step (top trace). The pipette was filled with the standard pipette solution and the holding potential was -10.4 $\mathrm{mV}$. The currents were recorded before application of mefloquine (a), $5.5 \mathrm{~min}$ (b) and 20 min (c) after the application of mefloquine, and $11 \mathrm{~min}$ after washout (d). Signals were filtered at a cut-off frequency of $10 \mathrm{kHz}$. Calibrations shown in the bottom trace apply to all. $E_{\mathrm{m}}$ : membrane potentials recorded in current clamp mode. Ba: Current obtained just before Ac using a shorter command pulse. $I_{0}$ is membrane current at the beginning of voltage step and $I_{\mathrm{ss}}$ is steady-state current. Broken line represents the holding current level. $\mathrm{Bb}$ : The decay of the capacitive current during the period indicated by the box in $\mathrm{Ba}$ was plotted with an expanded time-scale $(\mathrm{O}$, the number of data points was reduced for clarity). It was a good fit with the sum of two single exponential functions (continuous curve).

\section{Results}

The endothelial cells in the sheet preparations were electrically coupled to each other due to the numerous gap junctions. We have previously measured the input resistance to be around 2-3 $\mathrm{M} \Omega$ when a patch electrode was applied to one of the endothelial cells within such a preparation (Yamamoto and Suzuki, 2007). To control the membrane potential of the patched cell accurately, mefloquine, an antimalarial drug, was used as a gap junction blocker (Yamamoto and Suzuki, 2008). In the present experiments, mefloquine was evaluated more extensively as a gap junction blocker and then the ACh-induced membrane responses in vascular endothelial cells were analyzed while the gap junctions were effectively blocked by mefloquine.

The conventional whole-cell clamp method was applied to single endothelial cells, and changes in the time course of the current required to impose a $10 \mathrm{mV}$ voltage clamp step were used to determine the extent of coupling between cells (de Roos et al., 1996; Yamamoto and Suzuki, 1998). It can be seen in Fig. 1A that the current required to impose a $10 \mathrm{mV}$ command step effectively decreased $5.5 \mathrm{~min}$ after the application of mefloquine $(30 \mu \mathrm{M})$ and it was almost abolished after 20 
min. In the presence of mefloquine, only rapid capacitive currents and some sustained currents were observed. The membrane potential was also measured in the current clamp mode and it was found that mefloquine hyperpolarized the membrane as reported previously (Yamamoto and Suzuki, 2008). The effect of mefloquine was reversible and the current comparable to the control was obtained $11 \mathrm{~min}$ after the removal of mefloquine.

In the presence of mefloquine $(30 \mu \mathrm{M})$ the input resistance was calculated according to the following equations:

$$
R_{\mathrm{a}}=V_{\mathrm{P}} / I_{0} \text { and } R_{\text {in }}=\left(V_{\mathrm{P}}-R_{\mathrm{a}} I_{\mathrm{ss}}\right) / I_{\mathrm{ss}},
$$

where $R_{\mathrm{a}}$ is the access resistance, $V_{\mathrm{P}}$ the amplitude of voltage step, $I_{0}$ the membrane current at the beginning of voltage step and $I_{\mathrm{ss}}$ the steady-state current (Fig. $1 \mathrm{Ba}$ ). In 23 preparations the average $R_{\text {in }}$ was $229 \pm 90 \mathrm{M} \Omega$. Although this value was about a hundred times larger than the control value (2-3 M $\Omega$ ), it was much smaller than the value obtained in isolated single cells, which has been reported to be $1.7 \mathrm{G} \Omega$ in cultured guinea-pig coronary endothelial cells (Daut et al., 1988). Small numbers of gap junctions seemed to be still open in the presence of mefloquine. In the previous paper we fitted the relaxation of capacitive current induced by a step depolarization with a single exponential function (Yamamoto and Suzuki, 2008). But it was found in the present analysis that the sum of two exponential functions fitted the relaxation better than a single exponential function (Fig. 1Bb). The smaller time constant quite likely represented the charging process of the patched cell and the larger one the changing process of surrounding cells which had residual electrical couplings with the patched cell. The input capacitance $\left(C_{\text {in }}\right)$ of the patched cell was calculated according to the following equation:

$$
C_{\text {in }}=\tau \times\left(1 / R_{\mathrm{a}}+1 / R_{\text {in }}\right),
$$

where $\tau$ is the smaller time constant. In 23 preparations the average $C_{\text {in }}$ was $9.5 \pm 2.4 \mathrm{pF}$.

Mefloquine-induced membrane hyperpolarization was then examined (Fig. 2). At the time when the intercellular electrical coupling was effectively blocked by mefloquine $(30 \mu \mathrm{M})$, the membrane hyperpolarized in all 23 preparations examined (Fig. 2A). The membrane potentials in the absence and presence of mefloquine were $-14.8 \pm 1.8 \mathrm{mV}$ and $-24.4 \pm 3.2 \mathrm{mV}$, respectively ( $n$ $=23$ ), and are significantly different statistically. Recordings after washout of mefloquine were able to be continued in 10 out of 23 preparations with the membrane potential having returned to control level $(-17.3 \pm 2.1 \mathrm{mV}, n=10)$.

Mefloquine might increase the $\mathrm{Ca}^{2+}$ permeability of the membrane and increase $\left[\mathrm{Ca}^{2+}\right]_{\mathrm{i}}$. This would result in activation of $\mathrm{Ca}^{2+}$-activated $\mathrm{K}^{+}$channels and the induction of membrane hyperpolarization. To examine this possibility the membrane potential was recorded using the high-EGTA pipette solution which should prevent $\left[\mathrm{Ca}^{2+}\right]_{\mathrm{i}}$ elevation (Fig. $2 \mathrm{~B}$ ). The membrane potentials in the absence and presence of mefloquine were $-13.6 \pm 2.8 \mathrm{mV}$ and $-21.3 \pm 2.0 \mathrm{mV}$, respectively $(n=13)$, and $-16.6 \pm 3.7 \mathrm{mV}(n=6)$ after washout of mefloquine. The effect of mefloquine on the membrane potential was essentially the same irrespective of the intracellular EGTA concentration and the $\mathrm{Ca}^{2+}$ permeability was not likely to have been affected by mefloquine.

The membrane potential was then recorded using the high- $\mathrm{Cl}^{-}$pipette solution, which made $E_{\mathrm{Cl}}$ to be nearly zero (Fig. $2 \mathrm{C}$ ). The membrane potentials in the absence and presence of 


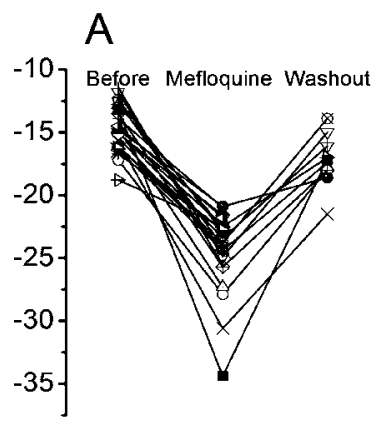

B

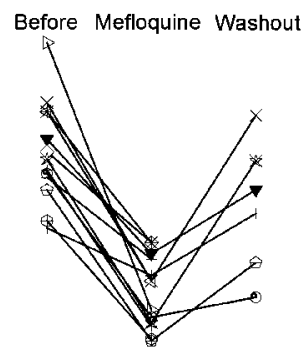

C

Before Mefloquine Washout

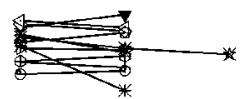

$\mathrm{mV}$

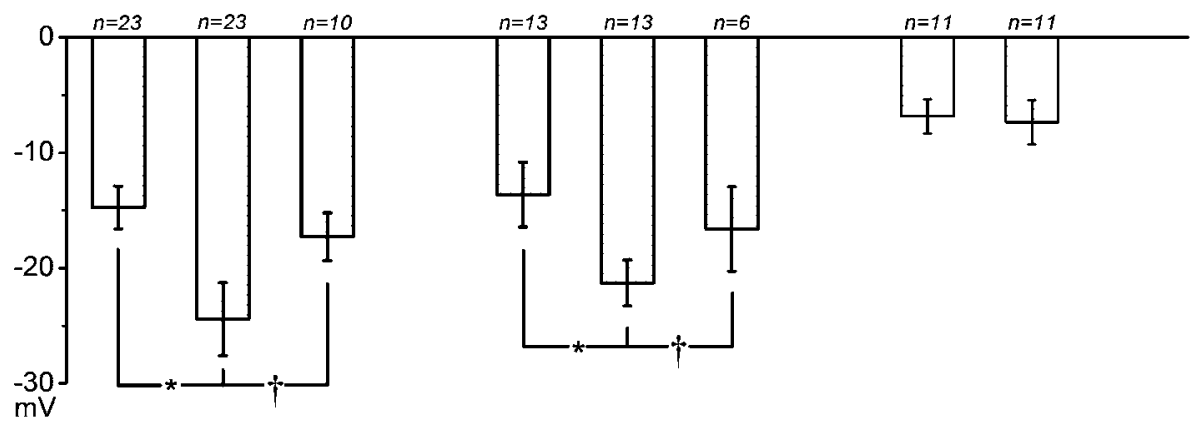

Fig. 2. Effect of mefloquine on the membrane potential under three different conditions. Upper panels: change of the membrane potentials before, during and after the application of mefloquine $(30 \mu \mathrm{M})$. Each symbol represents data from a separate experiment. Pipettes were filled with the standard pipette solution in A, the high-EGTA pipette solution in $\mathrm{B}$ and the high- $\mathrm{Cl}^{-}$pipette solution in $\mathrm{C}$. Lower panels: average membrane potentials before, during and after the application of mefloquine $(30 \mu \mathrm{M})$. Error bars represent the SDs. ${ }^{*}$, 'Significant difference (Student's paired* or unpaired ${ }^{\dagger} t$ test).

mefloquine were $-9.1 \pm 2.0 \mathrm{mV}$ and $-9.8 \pm 2.5 \mathrm{mV}$, respectively $(n=11)$, but without a mefloquine-induced hyperpolarization. This suggests that mefloquine might increase the membrane conductance for $\mathrm{Cl}^{-}$.

In mechanically-isolated population of endothelial cells where the input resistance is less than $100 \mathrm{M} \Omega$, the membrane potential can be controlled with a patch electrode (Yamamoto and Suzuki, 2007). In the presence of mefloquine the average input resistance was more than $200 \mathrm{M} \Omega$ and the membrane potential of a patched cell should be properly controlled. The membrane current was thus examined using the standard pipette solution after most of the gap junctions had been blocked by mefloquine. It was found that $\mathrm{ACh}(100 \mathrm{nM})$ induced a sustained outward current at the holding potential of $-10.4 \mathrm{mV}$ (Fig. 3A). As the reversal potential of the current represented the expected membrane potential if the voltage was not clamped, the membrane hyperpolarization down to -40 $\mathrm{mV}$ was estimated to be induced by ACh (Fig. 3A). The I-V relationship of the ACh-induced current component was then obtained and plotted (Fig. 3B). At the beginning of ACh application, the reversal potential of the $\mathrm{ACh}$-induced current was around $E_{\mathrm{K}}$, indicating that $\mathrm{K}^{+}$channels were activated quickly. The reversal potential then became less negative gradually and other ionic conductances having less negative equilibrium potentials seemed to gradually activate. Similar 
A
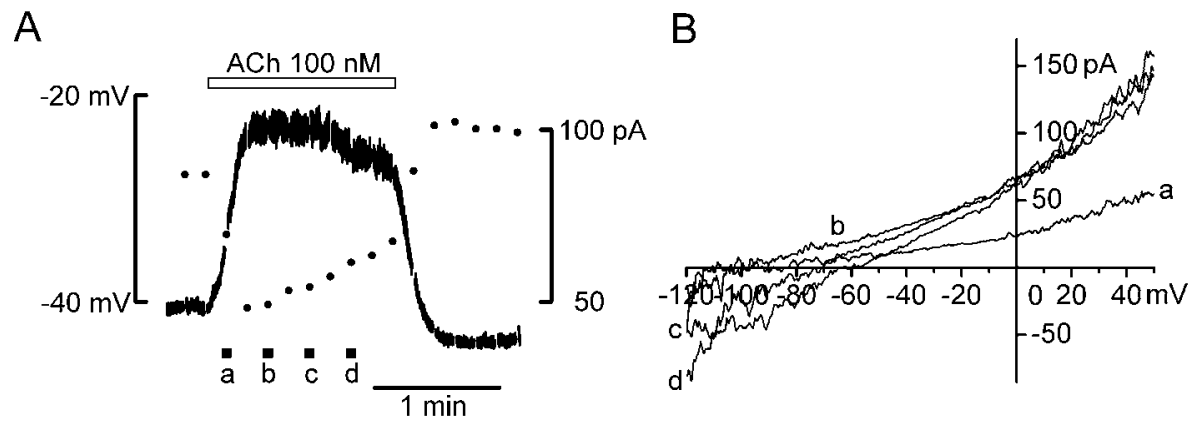

C

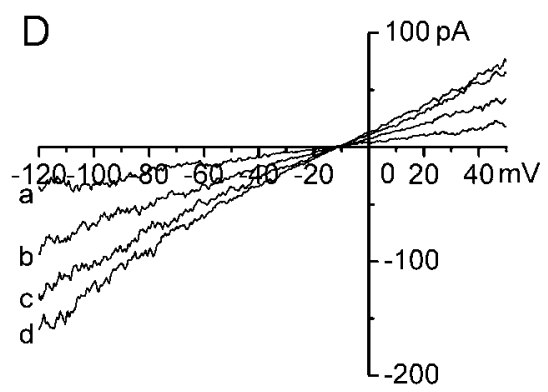

Fig. 3. ACh-induced membrane current in the presence of mefloquine. A: In the presence of mefloquine $(30 \mu \mathrm{M})$, application of $\mathrm{ACh}(100 \mathrm{nM})$ induced a sustained outward current at a holding potential of $-10.4 \mathrm{mV}$ (right axis). The voltage ramp was applied every $10 \mathrm{~s}$ and the measured reversal potentials $(\bullet)$ were plotted against the left axis. The pipette was filled with the standard pipette solution. B: $I-V$ relationships of the ACh-induced currents obtained at the points indicated by a-d in A. C: In the presence of mefloquine $(30 \mu \mathrm{M})$ and CTX $(100 \mathrm{nM})$, the ACh-induced outward current was absent. D: $I-V$ relationships of the $\mathrm{ACh}$-induced currents obtained at the points indicated by a-d in $\mathrm{C}$. Large currents during ramp applications were erased for clarity in A and C. A, B and C, $\mathrm{D}$ were recorded in different preparations.

responses were observed in 13 other preparations. ACh never induced the outward current in the presence of CTX $(100 \mathrm{nM})$ indicating that only CTX-sensitive $\mathrm{K}^{+}$channels were involved (Fig. 3C). Although no change was observed in the holding current in the presence of CTX, it was shown in the $I-V$ relationships that ACh gradually activated the membrane current which reversed polarity at around $-10 \mathrm{mV}$ (Fig. 3D). Similar responses were observed in seven other preparations.

The ACh-induced membrane current was then examined using the high- $\mathrm{Cl}^{-}$pipette solution in the presence of mefloquine (Fig. 4). ACh (100 nM) induced a sustained outward current at the holding potential of $-3.4 \mathrm{mV}$, and from the reversal potential of the current, a membrane hyperpolarization down to $-40 \mathrm{mV}$ was expected if the voltage was not clamped (Fig. 4A). The reversal potential of the ACh-induced current was around $E_{\mathrm{K}}$ at the beginning of ACh application, but then became less negative gradually (Fig. 4B). Similar responses were observed in eight other preparations. In the presence of CTX $(100 \mathrm{nM}) \mathrm{ACh}$ induced only a small change in the holding current (Fig. $4 \mathrm{C}$ ), and it was shown in the $I-V$ relationships that ACh gradually activated a membrane current with a reversal potential of about $-10 \mathrm{mV}$ (Fig. 4D). Similar responses were observed in two other preparations. 
A

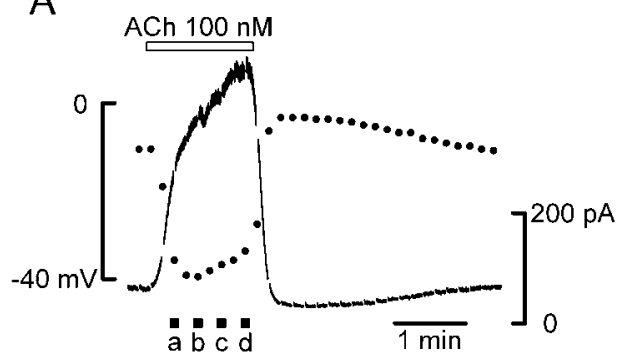

C

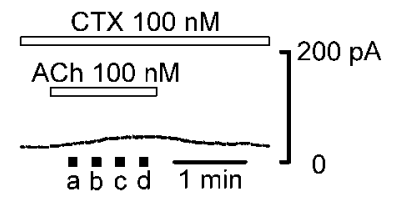

B

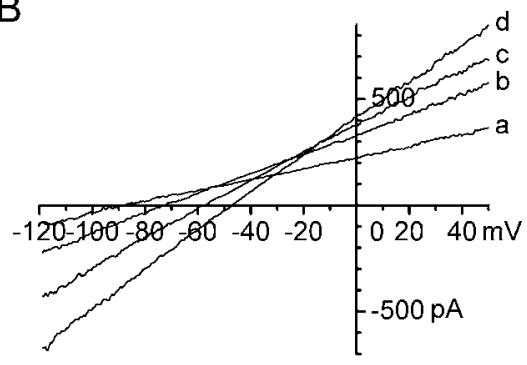

D

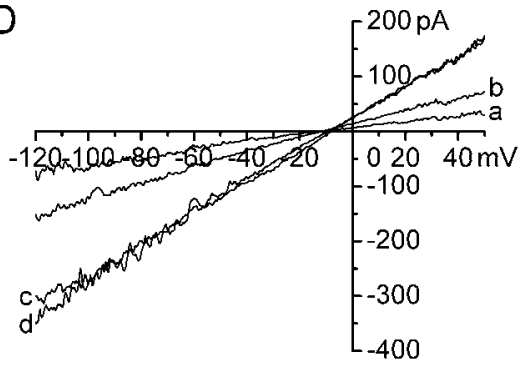

Fig. 4. ACh-induced membrane current in the presence of mefloquine under symmetrical $\mathrm{Cl}$ condition. A: In the presence of mefloquine $(50 \mu \mathrm{M})$, application of ACh $(100 \mathrm{nM})$ induced a sustained outward current at a holding potential of $-3.4 \mathrm{mV}$ (right axis). The voltage ramp was applied every $10 \mathrm{~s}$ and the measured reversal potentials $(\bullet)$ were plotted against the left axis. The pipette was filled with the high- $\mathrm{Cl}^{-}$pipette solution. B: $I-V$ relationships of the ACh-induced currents obtained at the points indicated by a-d in A. C: In the presence of mefloquine $(30 \mu \mathrm{M})$ and CTX $(100 \mathrm{nM}), \mathrm{ACh}$ induced only a small change in the holding current. D: $I-V$ relationships of the ACh-induced currents obtained at the points indicated by a-d in $\mathrm{C}$. Large currents during the ramp applications were erased for clarity in A and C. A, B and C, D were recorded in different preparations.

\section{Discussion}

The resting membrane potential of endothelial cells was $-15 \mathrm{mV}$ in the present experiments. It has previously been reported that the resting membrane potentials measured simultaneously in the smooth muscle and endothelial cells of guinea-pig mesenteric arterioles were both $-54 \mathrm{mV}$ (Yamamoto et al., 2001). In the intact tissue where the myoendothelial gap junctions are functioning, smooth muscle cells and endothelial cells are electrically coupled. Thus the membrane potentials of these electrically-coupled two groups of cells should influence each other making their membrane potentials similar. Once the endothelial cells are separated from the smooth muscle cells their membrane potentials would restore to the original membrane potential generated by these cells which seems to be less negative than that in the intact tissue. From this less negative potential, mefloquine hyperpolarized the membrane by some $10 \mathrm{mV}$. This effect was absent when $E_{\mathrm{Cl}}$ was near zero indicating that mefloquine might increase the membrane conductance for $\mathrm{Cl}^{\text {. }}$.

Besides this minor hyperpolarizing effect, mefloquine did not seem to have serious side effects. In the presence of mefloquine, $\mathrm{ACh}$ could activate an outward current producing a membrane hyperpolarization at concentrations as low as $100 \mathrm{nM}$. Because the threshold 
concentration of $\mathrm{ACh}$ to induce a hyperpolarization has been reported to be $30 \mathrm{nM}$ in the rat mesenteric artery (Crane et al., 2003) and $100 \mathrm{nM}$ in the guinea-pig carotid artery (Gluais $e$ t al., 2005), it would appear that mefloquine did not alter the sensitivity of endothelial cells to ACh.

To obtain the $I-V$ relationship of the ACh-induced current component, the $I-V$ relationship of the basal current should be subtracted from that of the original current in the presence of ACh. The current recorded just before a stimulation is usually used as the basal current under the assumption that the basal current is constant and not affected by the stimulation. In the present experiments, however, the basal current was not constant but actually decreased during ACh application, an effect that lasted for several minutes after the washout of ACh. Therefore, we used the current recorded not before the application of $\mathrm{ACh}$ but the current following the washout of $\mathrm{ACh}$ as the basal current. We are going to investigate this phenomenon in another series of experiments.

We found two ionic conductances which were activated by ACh. The quickly activated conductance had the reversal potential near $E_{\mathrm{K}}$ and was blocked by CTX indicating that it was a potassium conductance. The other conductance was activated more slowly and gradually. In our previous paper using a small number of mechanically-isolated cells instead of chemically-isolated cells with a gap junction blocker, we concluded that the second conductance was a $\mathrm{Cl}^{-}$one because it had a reversal potential near $E_{\mathrm{Cl}}$ and was blocked by so called $\mathrm{Cl}^{-}$channel blockers (Yamamoto and Suzuki, 2007). However, the calculated $E_{\mathrm{Cl}}$ might not be correct because the intracellular ionic conditions were difficult to control in these coupled cells. In the present experiments, the gap junctions between a patched cell and its neighboring cells had been blocked, and the intracellular perfusion of the patched cell should be rapid. After the liquid junction potentials were properly compensated for, we found that the reversal potential of the gradually activated current component was close to zero irrespective of $\left[\mathrm{Cl}^{-}\right]_{\mathrm{i}}$. Moreover, the effects of $\mathrm{Cl}^{-}$channel blockers are sometimes ambiguous as they have nonselective effects including gap junction blockade (Harks $e t$ al., 2001). Having the reversal potential near zero, the second conductance was most likely due to $\mathrm{Ca}^{2+}$-activated non-selective cation channels.

In the present study the ACh-induced $\mathrm{K}^{+}$current was completely blocked by CTX alone indicating that only $\mathrm{IK}_{\mathrm{Ca}}$ channels which are sensitive to CTX were activated by $\mathrm{ACh}$ in guinea-pig mesenteric artery endothelial cells. Agonist-induced endothelial hyperpolarization is mediated by both $\mathrm{IK}_{\mathrm{Ca}}\left(\mathrm{K}_{\mathrm{Ca}} 3.1\right)$ and $\mathrm{SK}_{\mathrm{Ca}}\left(\mathrm{K}_{\mathrm{Ca}} 2.3\right)$ channels in many kinds of vessels (Bychkov et al., 2002; Eichler et al., 2003; Gluais et al., 2005; Si et al., 2006). In some vascular beds, however, only $\mathrm{IK}_{\mathrm{Ca}}$ channels have been reported to be responsible (human mesenteric artery, Köhler et al., 2000; rat cerebral artery, Marrelli et al., 2003). The relatively thick portions of guinea-pig mesenteric artery that we used seem to belong to the latter group.

In conclusion, guinea-pig mesenteric artery endothelial cells have at least two $\mathrm{Ca}^{2+}$-activated ionic conductances. One is due to CTX-sensitive $\mathrm{IK}_{\mathrm{Ca}}$ channels that are activated quickly upon stimulation and the other is due to $\mathrm{Ca}^{2+}$-activated non-selective cation channels that are activated gradually. As the resting membrane potential of endothelial cells in intact tissue is between the reversal potentials of these two conductances, the former tends to hyperpolarize and the latter depolarize the membrane. These conductances may be responsible for the variety of agonistinduced membrane responses observed in many kinds of vascular preparations. 


\section{References}

Bychkov, R., Burnham, M.P., Richards, G.R., Edwards, G., Weston, A.H., Félétou, M. and Vanhoutte, P.M. (2002). Characterization of a charybdotoxin-sensitive intermediate conductance $\mathrm{Ca}^{2+}$-activated $\mathrm{K}^{+}$ channel in porcine coronary endothelium: relevance to EDHF. Br. J. Pharmacol. 137: 1346-1354.

Coleman, H.A., Tare, M. and Parkington, H.C. (2001). K ${ }^{+}$currents underlying the action of endotheliumderived hyperpolarizing factor in guinea-pig, rat and human blood vessels. J. Physiol.(Lond.) 531: 359-373.

Crane,G.J., Gallagher, N., Dora, K.A. and Garland, C.J. (2003). Small- and intermediate-conductance calcium-activated $\mathrm{K}^{+}$channels provide different facets of endothelium-dependent hyperpolarization in rat mesenteric artery. J. Physiol. (Lond.) 553: 183-189.

Cruikshank, S.J., Hopperstad, M., Younger, M., Connors, B.W., Spray, D.C. and Srinivas, M. (2004) . Potent block of Cx36 and Cx50 gap junction channels by mefloquine. Proc. Natl. Acad. Sci. U.S.A. 101: 12364-12369.

Daut, J., Mehrke, G., Nees, S. and Newman, W.H. (1988). Passive electrical properties and electrogenic sodium transport of cultured guinea-pig coronary endothelial cells. J. Physiol. (Lond.) 402: 237254.

de Roos, A.D.G., van Zoelen, E.J. J. and Theuvenet, A.P.R. (1996). Determination of gap junctional intercellular communication by capacitance measurements. Pflügers Arch. 431: 556-563.

Eichler, I., Wibawa, J., Grgic, I., Knorr, A., Brakemeier, S., Pries, A.R., Hoyer, J. and Köhler, R. (2003). Selective blockade of endothelial $\mathrm{Ca}^{2+}$-activated small- and intermediate-conductance $\mathrm{K}^{+}$-channels suppresses EDHF-mediated vasodilation. Br. J. Pharmacol. 138: 594-601.

Gluais, P., Edwards, G., Weston, A.H., Falck, J.R., Vanhoutte, P.M. and Félétou, M. (2005). Role of SK $\mathrm{Ca}_{\mathrm{C}}$ and $\mathrm{IK}_{\mathrm{Ca}}$ in endothelium-dependent hyperpolarizations of the guinea-pig isolated carotid artery. $\mathrm{Br}$. J. Pharmacol. 144: 477-485.

Grgic, I., Kaistha, B.P., Hoyer, J. and Köhler, R. (2009). Endothelial $\mathrm{Ca}^{2+}$-activated $\mathrm{K}^{+}$channels in normal and impaired EDHF-dilator responses-relevance to cardiovascular pathologies and drug discovery. Br. J. Pharmacol. 157: 509-526.

Harks, E.G.A., de Roos, A.D.G., Peters, P.H., de Haan, L.H., Brouwer, A., Ypey, D.L., van Zoelen, E.J.J. and Theuvenet, A.P.R. (2001). Fenamates: a novel class of reversible gap junction blockers. J. Pharmacol. Exp. Ther. 298: 1033-1041.

Köhler, R., Degenhardt, C., Kühn, M., Runkel, N., Paul, M and Hoyer, J. (2000). Expression and function of endothelial $\mathrm{Ca}^{2+}$-activated $\mathrm{K}^{+}$channels in human mesenteric artery. A single-cell reverse transcriptase-polymerase chain reaction and electrophysiological study in situ. Circ. Res. 87: 496503.

Marchenko S.M. and Sage S.O. (1993). Electrical properties of resting and acetylcholine-stimulated endothelium in intact rat aorta. J. Physiol. (Lond.) 462: 735-751.

Marrelli, S.P., Eckmann, M.S. and Hunte, M.S. (2003). Role of endothelial intermediate conductance $\mathrm{K}_{\mathrm{Ca}}$ channels in cerebral EDHF-mediated dilations. Am. J. Physiol. 285: H1590-H1599.

Si, H., Heyken, W.-T., Wölfle, S.E., Tysiac, M., Schubert, R., Grgic, I., Vilianovich, L., Giebing, G., Maier, T., Gross, V., Bader, M., de Wit, C., Hoyer, J. and Köhler, R. (2006). Impaired endotheliumderived hyperpolarizing factor-mediated dilations and increased blood pressure in mice deficient of the intermediate-conductance $\mathrm{Ca}^{2+}$-activated $\mathrm{K}^{+}$channel. Circ. Res. 99: 537-544.

Yamamoto, Y., Fukuta, H., Nakahira, Y. and Suzuki, H. (1998). Blockade by $18 \beta$-glycyrrhetinic acid of intercellular electrical coupling in guinea-pig arterioles. J. Physiol. (Lond.) 511: 501-508.

Yamamoto, Y., Imaeda, K. and Suzuki, H. (1999). Endothelium-dependent hyperpolarization and intercellular electrical coupling in guinea-pig mesenteric arterioles. J. Physiol. (Lond.) 514: 505513.

Yamamoto, Y., Klemm, M.F., Edwards, F.R. and Suzuki, H. (2001). Intercellular electrical communication among smooth muscle and endothelial cells in guinea-pig mesenteric arterioles. J. Physiol. (Lond.) 
535: $181-195$.

Yamamoto, Y and Suzuki, H. (2005). Dependency of endothelial cell function on vascular smooth muscle cells in guinea-pig mesenteric arteries and arterioles. J. Smooth Muscle Res. 41: 77-85.

Yamamoto, Y and Suzuki, H. (2007). Effects of increased intracellular $\mathrm{Cl}^{-}$concentration on membrane responses to acetylcholine in the isolated endothelium of guinea pig mesenteric arteries. $J$. Physiol. Sci. 57: 31-41.

Yamamoto, Y and Suzuki, H. (2008). Blockade by mefloquine of intercellular electrical coupling between vascular endothelial cells in the guinea-pig mesenteric arteries. J. Smooth Muscle Res. 44: 209215. 